\title{
Kinetics of $\left(\mathrm{TBAF}+\mathrm{CO}_{2}\right)$ semi-clathrate hydrate formation in the presence and absence of SDS
}

\author{
A. Mohammadi ${ }^{1}$ M. Pakzad $^{2}$ - A. H. Mohammadi ${ }^{3,4} \cdot$ A. Jahangiri $^{5}$
}

Received: 3 August 2017 / Published online: 24 March 2018

(C) The Author(s) 2018

\begin{abstract}
In this communication, the impacts of adding SDS (sodium dodecyl sulfate), TBAF (tetra- $n$-butylammonium fluoride) and the mixture of SDS + TBAF on the main kinetic parameters of $\mathrm{CO}_{2}$ hydrate formation (induction time, the quantity and rate of gas uptake, and storage capacity) were investigated. The tests were performed under stirring conditions at $T=5{ }^{\circ} \mathrm{C}$ and $P=3.8 \mathrm{MPa}$ in a $169 \mathrm{~cm}^{3}$ batch reactor. The results show that adding SDS with a concentration of $400 \mathrm{ppm}$, TBAF with a concentration of 1-5 wt $\%$, and the mixture of SDS + TBAF, would increase the storage capacity of $\mathrm{CO}_{2}$ hydrate and the quantity of gas uptake, and decrease the induction time of hydrate formation process. The addition of $5 \mathrm{wt} \%$ of TBAF and $400 \mathrm{ppm}$ of SDS would increase the $\mathrm{CO}_{2}$ hydrate storage capacity by $86.1 \%$ and $81.6 \%$, respectively, compared to pure water. Investigation of the impact of SDS, TBAF and their mixture on the rate of gas uptake indicates that the mixture of SDS + TBAF does not have a significant effect on the rate of gas uptake during hydrate formation process.
\end{abstract}

Keywords Semi-clathrate hydrate $\cdot$ Gas hydrate $\cdot$ Kinetics $\cdot \mathrm{CO}_{2} \cdot \mathrm{SDS} \cdot \mathrm{TBAF}$

\section{List of symbols}

$P$ Pressure

$R \quad$ Universal gas constant

$T$ Temperature

$V$ Volume of the gas phase

$Z$ Compressibility factor

\section{Subscripts}

0 Conditions of the cell at time $t=0$

$i$ Counter

\section{Edited Xiu-Qin Zhu}

A. Mohammadi

mohammadi.a@ub.ac.ir

1 Department of Chemical Engineering, University of Bojnord, Bojnord, Iran

2 Department of Chemical Engineering, Omidiyeh Branch, Islamic Azad University, Omidiyeh, Iran

3 Institut de Recherche en Génie Chimique et Pétrolier (IRGCP), Paris Cedex, France

4 Thermodynamics Research Unit, School of Engineering, University of KwaZulu-Natal, Howard College Campus, King George V Avenue, Durban 4041, South Africa

5 Faculty of Engineering, Shahrekord University, Shahrekord, Iran $t \quad$ Time

w Water

\section{Introduction}

According to the Paris Agreement on Climate Change (2015), 195 United Nations members states agreed to reduce their carbon output as soon as possible (UNFCCC 2015). ${ }^{1} \mathrm{CO}_{2}$, one of the main human-produced greenhouse gases, is a by-product of energy related industries (especially power plants) (Bhattacharjee et al. 2015). The quantity of $\mathrm{CO}_{2}$ in the atmosphere has increased considerably in recent decades. Therefore, the capture and sequestration (storage) of $\mathrm{CO}_{2}$ have become a priority within energy research. Chemical and physical absorption and chemical adsorption on zeolite are common ways to separate $\mathrm{CO}_{2}$ from gas mixtures (Herzog et al. 1997; Kohl and Nielsen 1997; Kuramochi et al. 2012; Peng and Zhuang 2012; Riemer 1996). These technologies are generally expensive and thus finding an energy efficient method to capture $\mathrm{CO}_{2}$ molecules is necessary. One of new and promising methods to separate $\mathrm{CO}_{2}$ from flue/industrial gases is using gas hydrate technology.

\footnotetext{
${ }^{1}$ United Nations Framework Convention on Climate Change.
} 
Gas hydrates or clathrate hydrates are ice-like non-stoichiometric crystalline inclusion compounds that are formed by enclathration of some guest molecules of certain sizes (such as methane, $\mathrm{CO}_{2}$ and hydrogen sulfide.) into a three-dimensional network of hydrogen-bonded water (host) molecules (Kang and Lee 2010; Sloan 2011; Sloan and Koh 2008). Due to high gas and energy storage capacity of gas hydrates and their potential for separation processes, great attention has been paid to the positive applications of this technology (such as natural gas storage and transportation, gas separation, energy storage, water desalination, refrigeration systems, and so on (Adisasmito et al. 1991; Chatti et al. 2005; Eslamimanesh et al. 2012; Javanmardi and Moshfeghian 2003; Ji et al. 2001; Li et al. 2012; Ohgaki et al. 1996; Xu and Ge 2011; Tanii 1994), in recent years. However, high pressure/low temperature dissociation conditions, long induction time, and slow kinetic rate of hydrate growth are the major problems with using gas hydrates in gas industries (Babaee et al. 2015; Mohammadi et al. 2014a; Zhang et al. 2008). Therefore, moderating the thermodynamic conditions and promoting the kinetics of gas hydrate formation are essential to benefit the positive applications of this technology and thus reliable design of hydrate-based industries. The moderating of thermodynamic conditions of gas hydrate formation has been the objective of many research studies in recent decades (Delahaye et al. 2006; Jager et al. 1999; Lu et al. 2009; Manteghian et al. 2013; Papadimitriou et al. 2011; Strobel et al. 2006; Sun et al. 2010; Zhang and Wu 2010; Zhang et al. 2006, 2009; Zhao et al. 2008).

In 1940, Fowler et al. discovered a new structure of the hydrates, which is formed by tetra-n-butylammonium salts (Fowler et al. 1940). Because in these structures some water lattice sites are replaced by the guest molecules (anions), they are called semi-clathrates. In semi-clathrates formed by tetra-n-butylammonium salts, tetra- $n$-butylammonium chains occupy the large cages and the small cages remain vacant or partially occupied with water molecules or small gas molecules (Bonamico et al. 1962; Fowler et al. 1940; Hughes 2008; Komarov et al. 2007; Makino et al. 2009; McMullan et al. 1963; Mohammadi et al. 2013, 2014b). Mohammadi and coworkers have widely investigated the thermodynamic conditions of gas hydrate formation in the presence of some semi-clathrate formers such as tetra- $n$-butylammonium fluoride (TBAF), tetra- $n$ butylammonium chloride (TBAC), and tetra-n-butylammonium bromide (TBAB) (Belandria et al. 2011, 2012; Mohammadi et al. 2013, 2014b; Mohammadi et al. 2012; Mohammadi and Richon 2009). They found that the presence of studied semi-clathrate formers moderates the thermodynamics of gas hydrate formation dramatically (Belandria et al. 2011, 2012; Mohammadi et al. 2013, 2014b, 2012; Mohammadi and Richon 2009).
Despite a large number of studies undertaken on the thermodynamics of semi-clathrate hydrates, few attempts have been made to investigate the kinetics of this type of hydrates (Fan et al. 2011; Ye et al. 2014).

In recent years, the kinetic parameters of clathrate hydrate formation (such as induction time, the quantity of gas uptake and growth rate) in the presence of different additives have been studied by many researchers (Arjang et al. 2013; Bi et al. 2009; Dashti et al. 2015; Farhang et al. 2014; Fazlali et al. 2013; Ganji et al. 2007a, b; Kang and Lee 2010; Kumar et al. 2013; Lirio et al. 2013; Manteghian et al. 2013; Mohammadi et al. 2014a; Ricaurte et al. 2014; Rogers et al. 2007; Roosta et al. 2015; Sabil et al. 2010; Torré et al. 2011; Zhang et al. 2004, 2007). Mohammadi and coworkers studied the impact of sodium dodecyl sulfate and silver nanoparticles on the kinetic parameters of $\mathrm{CO}_{2}$ clathrate hydrate formation (Mohammadi et al. 2014a). Their results show that simultaneous utilization of SDS and silver nanoparticles increases the hydrate formation rate, storage capacity and the quantity of gas uptake during hydrate formation considerably (Mohammadi et al. 2014a). Kang et al. investigated the kinetic behavior of $\mathrm{CO}_{2}$ hydrate formation in porous media in the presence of SDS. They showed that adding SDS increases the initial $\mathrm{CO}_{2}$ hydrate formation rate, compared to pure water. The investigation of Kumar and coworkers (Kumar et al. 2013) on the impact of different additives (Tween-80, dodecyltrimethylammonium chloride (DTACl), and SDS) on $\mathrm{CO}_{2}$ hydrate formation kinetics show that SDS is probably the most effective among their studied additives (Kumar et al. 2013). Although, the kinetics of $\mathrm{CO}_{2}$ "clathrate" hydrate formation in the presence of surfactants have been studied by some researchers, in recent years, the kinetics of $\mathrm{CO}_{2}$ hydrate formation in the presence of "semi-clathrate" formers (that moderate the thermodynamics of gas hydrate formation noticeably) requires more attention.

In the present study, the impacts of SDS, TBAF, and the mixture of SDS + TBAF on the induction time, the quantity of gas uptake, the hydrate growth rate, and the storage capacity of $\mathrm{CO}_{2}$ hydrate formation process were investigated.

\section{Experimental}

\subsection{Materials and apparatus}

The purities and suppliers of the materials used in this work are reported in Table 1.

The experimental apparatus is fully described elsewhere (Mohammadi et al. 2014a). Figure 1 shows the schematic picture of the apparatus. Briefly, the hydrate formation reactor with an effective volume of $169 \mathrm{~cm}^{3}$, is a jacketed 
Table 1 Purities and suppliers of the materials used in this work

\begin{tabular}{lll}
\hline Chemical & Supplier & Purity \\
\hline $\mathrm{SDS}$ & Daejung Chemical \& Metal Co. Ltd. (Korea) & $98 \mathrm{wt} \%$ \\
$\mathrm{CO}_{2}$ & Sepehr gas (Iran) & $99.99 \mathrm{~mol} \%$ \\
$\mathrm{TBAF}$ & Merck (Germany) & $97 \mathrm{~mol} \%$ \\
\hline
\end{tabular}

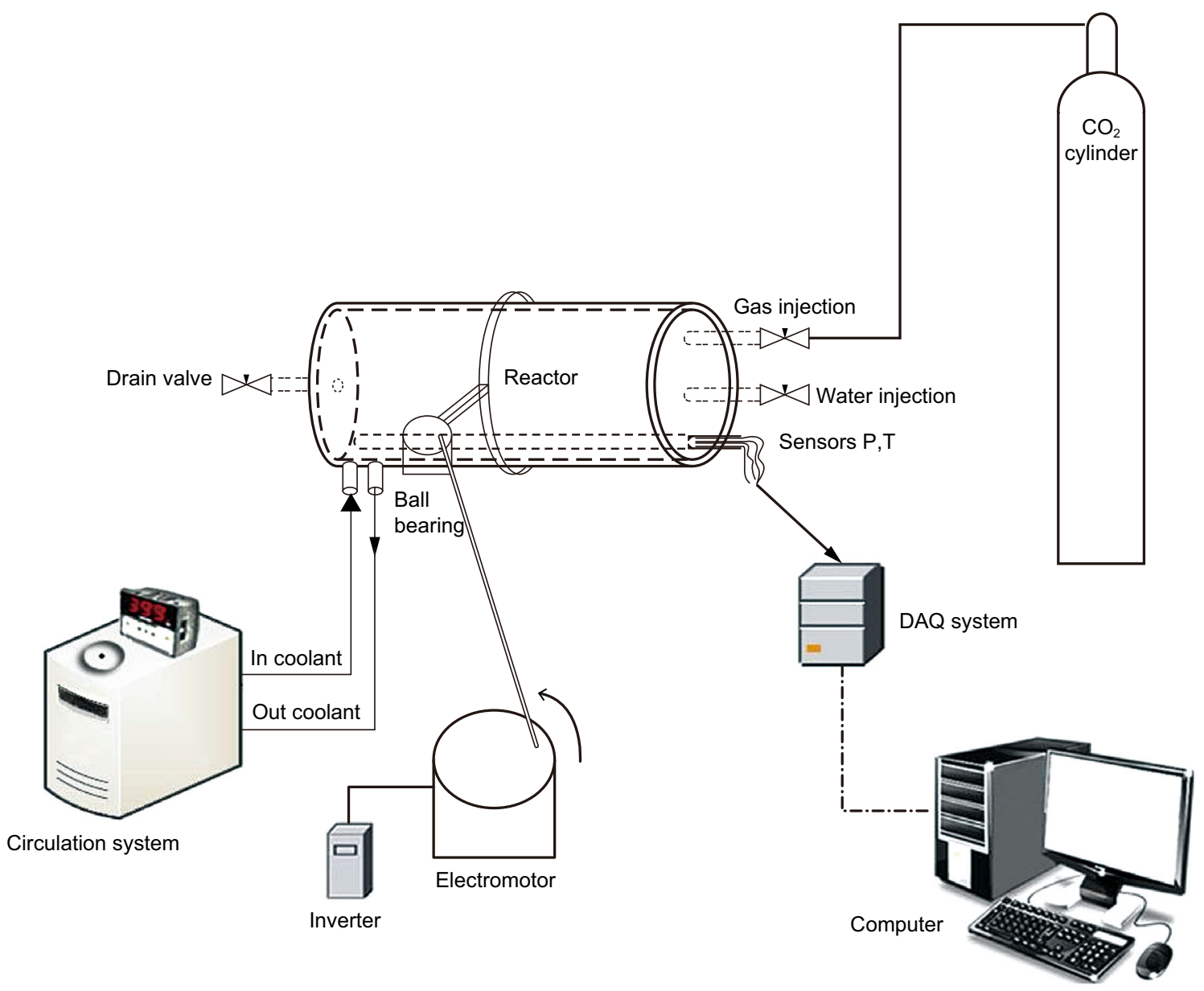

Fig. 1 Schematic illustration of the experimental apparatus used in this study

stainless steel cell. For appropriate mixing of the gas, aqueous solution and hydrate, an electric motor is used to rock the reactor. The stirring rate of the reactor is $10 \mathrm{rpm}$.

\subsection{Procedure}

Experiments were carried out at the Central Laboratory of Gas Conversions at the University of Bojnord, Iran. At first, the cell was washed with distilled water. To ensure that all parts of the set up are free of air, inner parts were evacuated with a vacuum pump. $50 \mathrm{~cm}^{3}$ of prepared solution was loaded into the cell at room temperature and atmospheric pressure. Then, the temperature of the reactor was set to the desired temperature of $5{ }^{\circ} \mathrm{C}$. To achieve the desired pressure (3.8 $\mathrm{MPa}$ ), the cell was charged with $\mathrm{CO}_{2}$.
After the reactor was pressurized with $\mathrm{CO}_{2}$, the electric motor was turned on with a speed of $10 \mathrm{rpm}$. The cell pressure decreased continuously due to hydrate formation until reaching a steady state condition. During the experiments, the cell temperature and pressure were recorded by the digital acquisition (DAQ) system.

\section{Results and discussion}

The phase equilibrium conditions for hydrate-containing systems of TBAF have been studied by some researchers. Mohammadi and coworkers (Mohammadi et al. 2013) and $\mathrm{Li}$ and coworkers ( $\mathrm{Li}$ et al. 2010) determined the semiclathrate hydrate phase equilibria of water $+\operatorname{TBAF}(2,4$, 


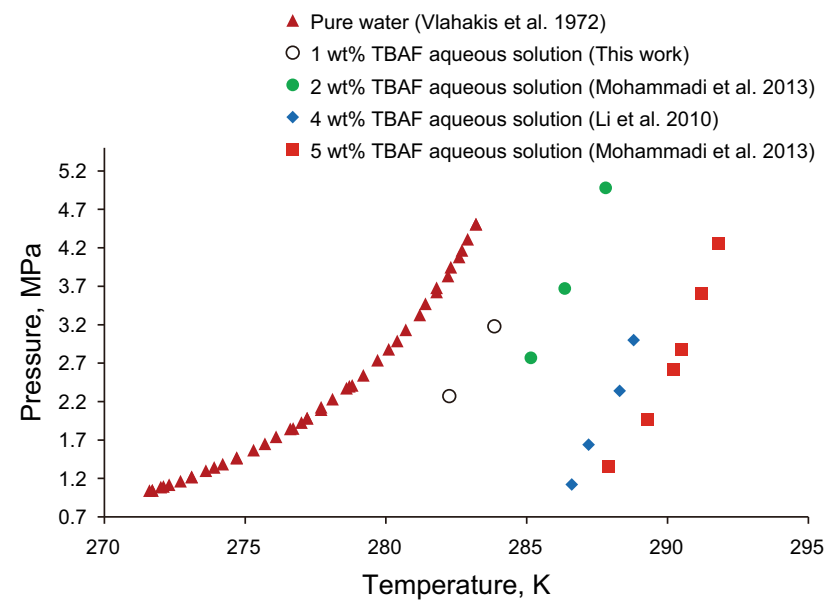

Fig. 2 Semi-clathrate hydrate phase equilibria of carbon dioxide $+\mathrm{TBAF}+$ water systems

and $5 \mathrm{wt} \%)+\mathrm{CO}_{2}$ systems. In this study, we measured the phase equilibrium conditions for $1 \mathrm{wt} \%$ of TBAF. The results of the measurements are shown in Fig. 2.

\subsection{Quantity and rate of gas uptake}

The impact of adding TBAF, SDS, and the mixture of $\mathrm{TBAF}+\mathrm{SDS}$ on the quantity of $\mathrm{CO}_{2}$ uptake, induction time, and rate of gas uptake during $\mathrm{CO}_{2}$ hydrate formation were investigated, as mentioned earlier (Mohammadi et al. 2014a). The kinetics of hydrate formation was studied in a stirred batch reactor at the temperature of $5{ }^{\circ} \mathrm{C}$ and the pressure of $3.8 \mathrm{MPa}$, as pointed out earlier. Aqueous solutions of (a) TBAF with concentrations of $0,1,4$, and $5 \mathrm{wt} \%$, (b) SDS with concentrations of 0 and $400 \mathrm{ppm}$, and (c) SDS $400 \mathrm{ppm}+\mathrm{TBAF}(0-4) \mathrm{wt} \%$ were prepared, in order to investigate the impacts of SDS, TBAF, and $\mathrm{SDS}+\mathrm{TBAF}$ on the kinetics of $\mathrm{CO}_{2}$ hydrate formation.

The quantity of gas uptake during $\mathrm{CO}_{2}$ hydrate formation process can be calculated by employing the real gas law (Eq. (1) (Mohammadi et al. 2014a; Smith et al. 2001).

$\Delta n_{\mathrm{CO}_{2}}=\frac{P_{0} V_{0}}{Z_{0} R T_{0}}-\frac{P_{t} V_{t}}{Z_{t} R T_{t}}$

where $P$ is the pressure; $T$ represents the temperature; $V$ stands for the volume of the gas inside the reactor; $Z$ is the gas compressibility factor; $R$ represents the universal gas constant; and subscripts 0 and $t$ stand for conditions of the cell at time $t=0$ and time $t$, respectively.

The quantities of $\mathrm{CO}_{2}$ uptake during hydrate formation for the systems of $\mathrm{CO}_{2}+$ water and $\mathrm{CO}_{2}+$ water $+\operatorname{TBAF}(1,4$, and $5 \mathrm{wt} \%)$ are depicted in Fig. 3. As shown in this Fig. 3, adding aqueous solution of TBAF (1, 4 , and $5 \mathrm{wt} \%$ ) increases the quantities of $\mathrm{CO}_{2}$ uptake within $60 \mathrm{~min}$ of hydrate formation experiments, compared

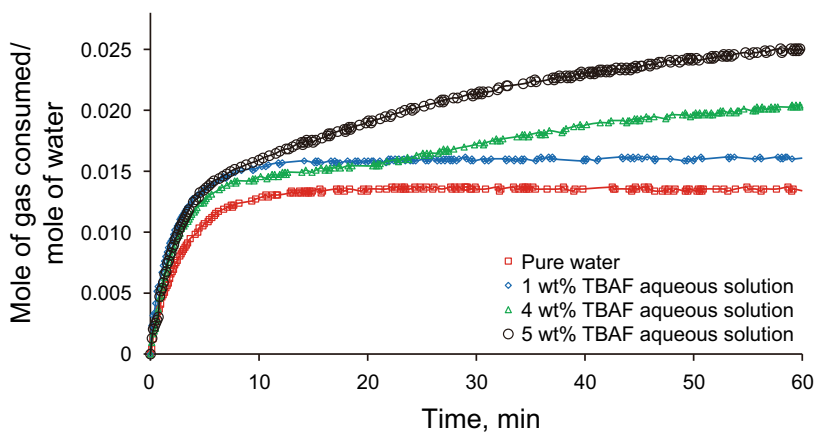

Fig. 3 The quantities of $\mathrm{CO}_{2}$ uptake during hydrate formation in the absence and the presence of TBAF with various concentrations at an initial pressure of $3.8 \mathrm{MPa}$ and temperature of $5{ }^{\circ} \mathrm{C}$

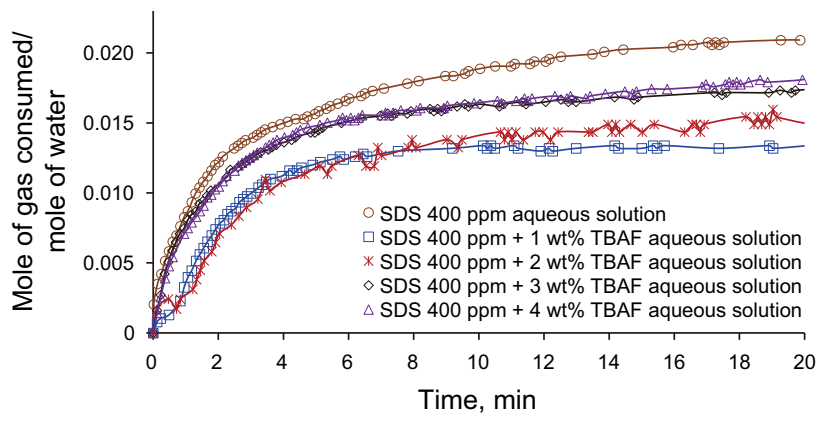

Fig. 4 The quantities of $\mathrm{CO}_{2}$ uptake during hydrate formation in the presence of SDS $400 \mathrm{ppm}$ and the various concentrations of TBAF at an initial pressure of $3.8 \mathrm{MPa}$ and temperature of $5{ }^{\circ} \mathrm{C}$

to pure water and the quantity of gas uptake during hydrate formation is proportional to the concentration of TBAF.

The maximum quantity of $\mathrm{CO}_{2}$ uptake was obtained for $5 \mathrm{wt} \% \mathrm{TBAF}$ aqueous solution. At $t=60 \mathrm{~min}$, the quantity of $\mathrm{CO}_{2}$ consumption per mole of feed water for this solution was found to be $0.1382 \mathrm{~mol}$ compared to pure water having $0.0742 \mathrm{~mol}$. This means that adding $5 \mathrm{wt} \%$ of TBAF increases the quantity of $\mathrm{CO}_{2}$ uptake $86 \%$, compared to pure water. By increasing the concentration of TBAF from 1 to $5 \mathrm{wt} \%$, the thermodynamics of hydrate formation are moderated (Mohammadi et al. 2013). Therefore, the driving force of $\mathrm{CO}_{2}$ hydrate formation increases. Increasing the driving force of hydrate formation process increases the quantity of gas uptake.

Figure 4 illustrates the quantity of $\mathrm{CO}_{2}$ uptake per mole of water during hydrate formation process in the presence of SDS (400 ppm) and the various concentrations of TBAF at an initial pressure of $3.8 \mathrm{MPa}$ and temperature of $5{ }^{\circ} \mathrm{C}$. As shown in Fig. 4, simultaneous utilization of SDS (400 ppm) and TBAF (1-4 wt \%) decreases the quantity of gas uptake within $20 \mathrm{~min}$ of hydrate formation experiments, compared to the system of $\mathrm{CO}_{2}+\mathrm{SDS}$ $(400 \mathrm{ppm})+$ water. In other words, adding TBAF (with concentration of (1-4 wt $\%)$ to aqueous solution of SDS 
(with concentration of $400 \mathrm{ppm}$ ) results in a negative effect on the quantity of gas uptake during hydrate formation.

A likely reason for this phenomenon is as follows: The strong interaction between the ions of $\mathrm{Na}^{+}$(released from SDS) and $\mathrm{F}^{-}$(in the lattice structure of semi-clathrate hydrates) results in a negative effect on the stability of semi-clathrate lattice structure and consequently, the quantity of trapped gases will be decreased.

As shown in Fig. 4, by increasing the concentration of TBAF from 1 to $4 \mathrm{wt} \%$ at constant concentration of SDS (400 ppm), the quantity of $\mathrm{CO}_{2}$ uptake during hydrate formation process increases. By increasing the concentration of TBAF (from 1 to $4 \mathrm{wt} \%$ ) at constant concentration of SDS (400 ppm), the quantity of $\mathrm{Na}^{+}$per mole of $\mathrm{F}^{-}$ decreases. Therefore, the negative effect of $\mathrm{Na}^{+}$on the stability of semi-clathrate hydrate lattice decreases and consequently, the quantity of gas consumption would increase.

Figures 5, 6 and 7 depict the impact of adding SDS on the quantity of $\mathrm{CO}_{2}$ uptake during hydrate formation process. Figure 5 shows the impact of SDS on the quantity of $\mathrm{CO}_{2}$ consumption in the absence of TBAF. As shown in this figure, adding SDS increases the quantity of gas uptake during hydrate formation. SDS increases the solubility of $\mathrm{CO}_{2}$ in water by decreasing the surface tension of water molecules at the gas-liquid interface.

The impact of SDS on the quantity of $\mathrm{CO}_{2}$ uptake during hydrate formation in the presence of $1 \mathrm{wt} \% \mathrm{TBAF}$ at an initial pressure of $3.8 \mathrm{MPa}$ and temperature of $5{ }^{\circ} \mathrm{C}$ is illustrated in Fig. 6. As shown in this figure, at low concentration of TBAF, the presence of SDS -by decreasing the stability of semi-clathrate lattice- causes a negative effect on the quantity of gas uptake during hydrate formation process.

Figure 7 depicts the impact of SDS on the quantity of $\mathrm{CO}_{2}$ uptake during hydrate formation in the presence of $4 \mathrm{wt} \%$ of TBAF. As illustrated in this figure, at this

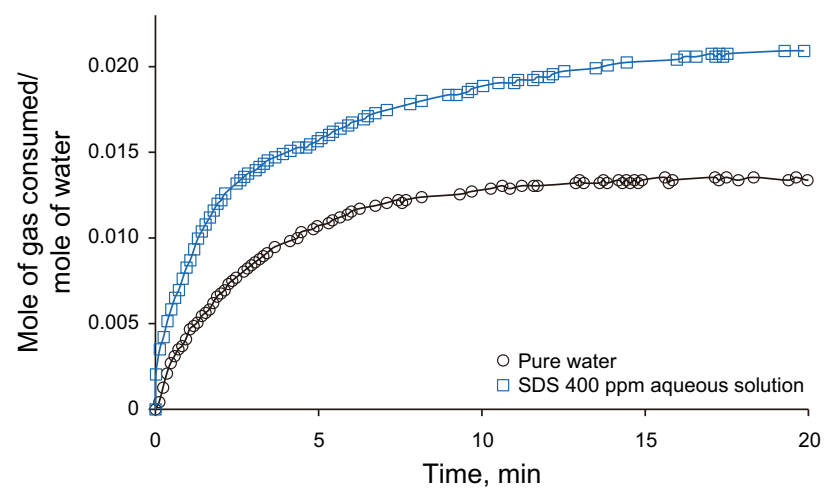

Fig. 5 The impact of adding SDS on the quantity of $\mathrm{CO}_{2}$ uptake during hydrate formation at an initial pressure of $3.8 \mathrm{MPa}$ and temperature of $5{ }^{\circ} \mathrm{C}$

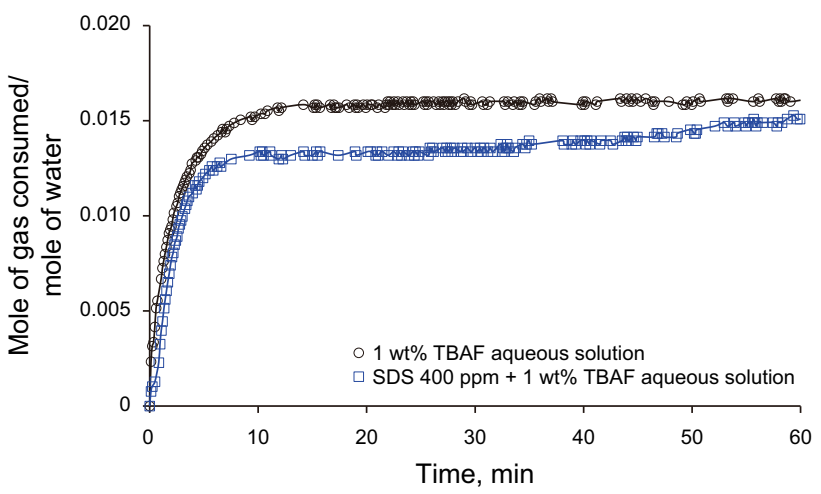

Fig. 6 The impact of SDS on the quantity of $\mathrm{CO}_{2}$ uptake during hydrate formation in the presence of $1 \mathrm{wt} \% \mathrm{TBAF}$ aqueous solution at an initial pressure of $3.8 \mathrm{MPa}$ and temperature of $5{ }^{\circ} \mathrm{C}$

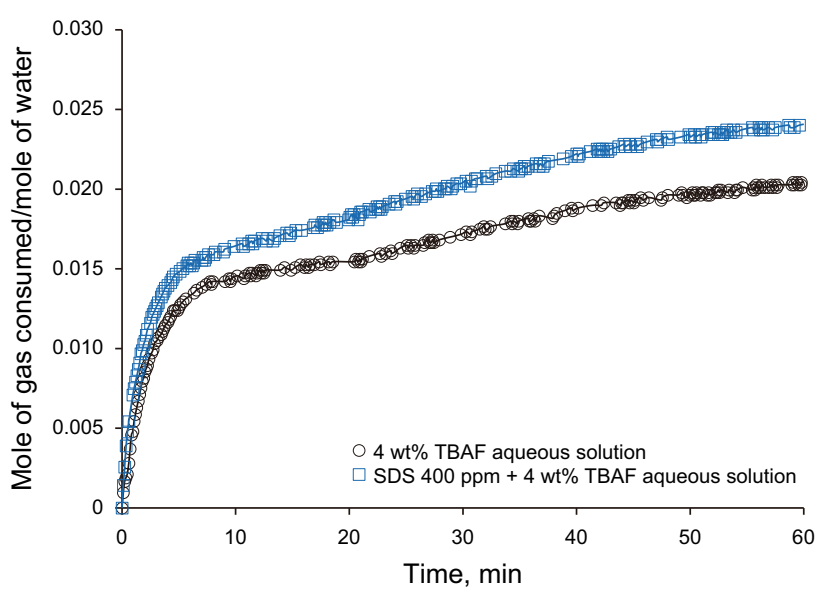

Fig. 7 The impact of SDS on the quantity of $\mathrm{CO}_{2}$ uptake during hydrate formation in the presence of $4 \mathrm{wt} \% \mathrm{TBAF}$ aqueous solution, at an initial pressure of $3.8 \mathrm{MPa}$ and temperature of $5{ }^{\circ} \mathrm{C}$

concentration of TBAF, the presence of SDS has a positive effect on the quantity of gas uptake during hydrate formation process. At this concentration of TBAF, the quantity of $\mathrm{Na}^{+}$per mole of $\mathrm{F}^{-}$decreases, compared to $1 \mathrm{wt} \%$ aqueous solution of TBAF. Therefore, the negative effect of $\mathrm{Na}^{+}$on the stability of semi-clathrate lattice decreases. On the other hand, SDS decreases the surface tension of water molecules. Therefore, the quantity of $\mathrm{CO}_{2}$ consumption in the presence of SDS is higher than that of in the absence of SDS.

Equation (2) was employed to calculate the rate of gas uptake, $r(t)$, during hydrate formation process (Mohammadi et al. 2014a):

$r(t)=\frac{n_{\mathrm{CO}_{2}, i-1}-n_{\mathrm{CO}_{2}, i+1}}{\left(t_{i+1}-t_{i-1}\right) n_{\mathrm{w}_{0}}}$

where $n_{\mathrm{CO}_{2}, i-1}$ and $n_{\mathrm{CO}_{2}, i+1}$ are, respectively, the mole number of $\mathrm{CO}_{2}$ in the gas phase at $t_{i-1}$ and $t_{i+1}$; and $n_{\mathrm{w}_{0}}$ is the initial mole number of water. 


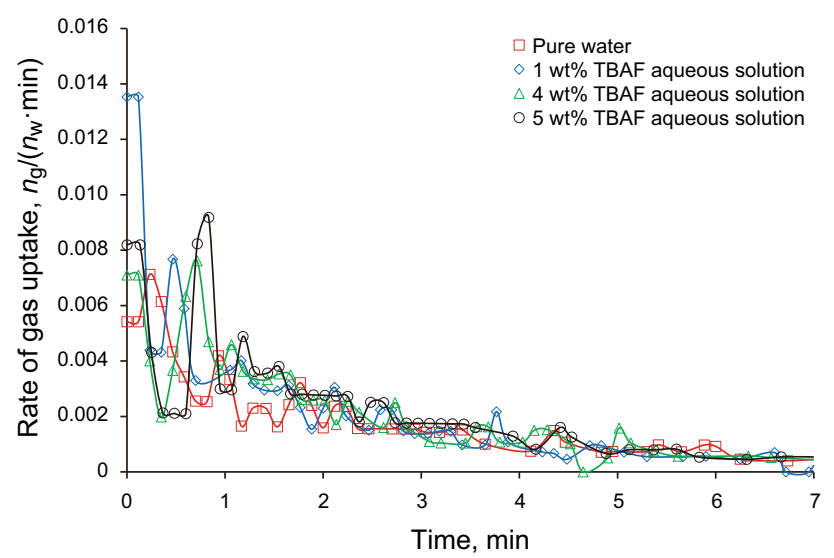

Fig. 8 The rate of $\mathrm{CO}_{2}$ uptake during hydrate formation in the presence of TBAF aqueous solution with different concentrations, at an initial pressure of $3.8 \mathrm{MPa}$ and temperature of $5{ }^{\circ} \mathrm{C}$

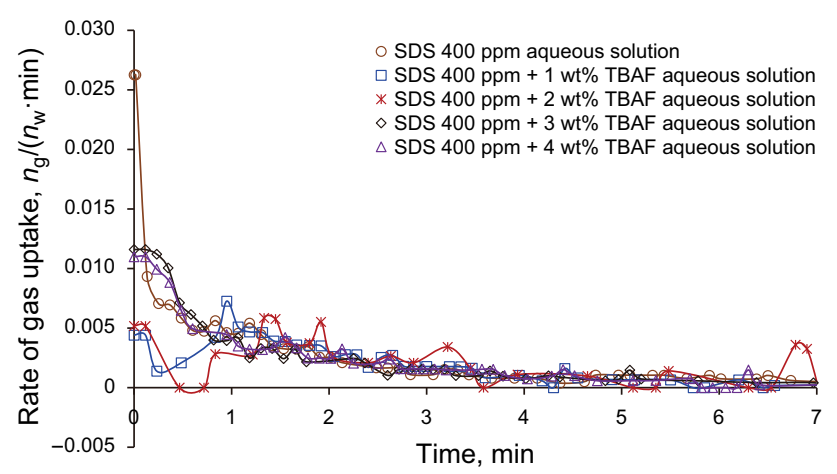

Fig. 9 The rate of $\mathrm{CO}_{2}$ uptake during hydrate formation in the presence of SDS $400 \mathrm{ppm}$ and TBAF aqueous solution with different concentrations, at an initial pressure of $3.8 \mathrm{MPa}$ and temperature of $5{ }^{\circ} \mathrm{C}$

Figures 8 and 9, respectively, show the impacts of different concentrations of TBAF on the rate of $\mathrm{CO}_{2}$ consumption in the absence and the presence of SDS (with concentration of $400 \mathrm{ppm})$. As shown in these figures (Figs. 8, 9), the time range of rapid $\mathrm{CO}_{2}$ consumption for the systems of $\mathrm{CO}_{2}+$ water and $\mathrm{CO}_{2}$ $+\mathrm{TABF}+$ water was $0-5 \mathrm{~min}$. This time range was 0-3 min for the systems of $\mathrm{CO}_{2}+\mathrm{SDS}+$ water, and $\mathrm{CO}_{2}+\mathrm{SDS}+\mathrm{TABF}+$ water. The rate of gas consumption tended to a very small value, after these time periods. As shown in these figures, the addition of TBAF does not have a significant effect on increasing the gas consumption rate.

The impact of SDS (with concentration of $400 \mathrm{ppm}$ ) on the rate of $\mathrm{CO}_{2}$ uptake during hydrate formation process is illustrated in Figs. 10, 11 and 12. It can be seen that, adding SDS with concentration of $400 \mathrm{ppm}$ does not have a significant effect on increasing the gas consumption rate.

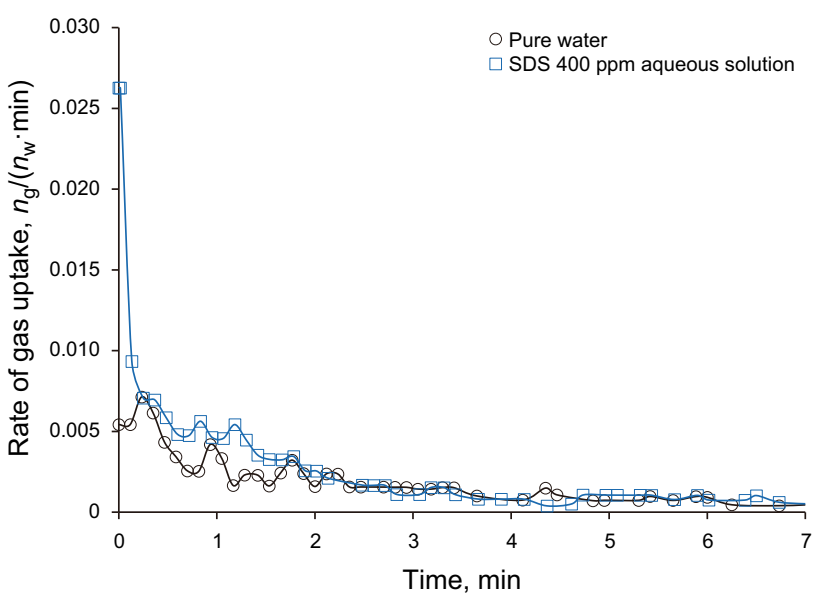

Fig. 10 The impact of SDS on the rate of $\mathrm{CO}_{2}$ uptake during hydrate formation at an initial pressure of $3.8 \mathrm{MPa}$ and temperature of $5{ }^{\circ} \mathrm{C}$

\subsection{Impact of SDS and TBAF on induction time and storage capacity of $\mathrm{CO}_{2}$}

Figure 13 depicts the induction time of $\mathrm{CO}_{2}$ hydrate formation for the systems of $\mathrm{CO}_{2}+$ water, $\mathrm{CO}_{2}$ $+\mathrm{TABF}+$ water, $\quad \mathrm{CO}_{2}+\mathrm{SDS}+$ water, and $\mathrm{CO}_{2}+\mathrm{SDS}+\mathrm{TABF}+$ water. The numerical data of induction times are given in Table 2. In this study, the induction time is defined as the time from introducing the gas to the cell to the time of initial formation of hydrate. As shown in Fig. 13 and Table 2, all the tested additives decrease the induction time of hydrate formation. Adding SDS decreases the induction time of $\mathrm{CO}_{2}$ hydrate formation considerably. The induction time of $\mathrm{CO}_{2}$ hydrate formation in the presence of $400 \mathrm{ppm}$ SDS is $0.4 \mathrm{~min}$, while this value is $73 \mathrm{~min}$ for the system of $\mathrm{CO}_{2}+$ water. Adding $5 \mathrm{wt} \%$ TBAF decreases the induction time of $\mathrm{CO}_{2}$ hydrate formation noticeably, compared to pure water. The induction time of hydrate formation for the system of $\mathrm{CO}_{2}+5 \mathrm{wt} \% \mathrm{TABF}+$ water is $0.9 \mathrm{~min}$ at initial pressure of $3.8 \mathrm{MPa}$ and temperature of $5^{\circ} \mathrm{C}$. SDS improves the induction time of hydrate formation process by decreasing the surface tension of water molecules and TBAF and by increasing the driving force of $\mathrm{CO}_{2}$ hydrate formation.

Figure 14 shows the impacts of adding SDS, TBAF, and the mixture of SDS + TBAF on storage capacity of $\mathrm{CO}_{2}$ within $60 \mathrm{~min}$ of experiments of the hydrate formation at an initial pressure of $3.8 \mathrm{MPa}$ and temperature of $5^{\circ} \mathrm{C}$. The numerical data of storage capacities are given in Table 3. As shown in Fig. 14 and Table 3, all the tested additives increased the storage capacity of $\mathrm{CO}_{2}$ in the process of hydrate formation, compared to pure water.

The storage capacity of $\mathrm{CO}_{2}$ hydrate for $5 \mathrm{wt} \%$ TBAF aqueous solution was $60.6 \mathrm{v} / \mathrm{v}$, compared to pure water 


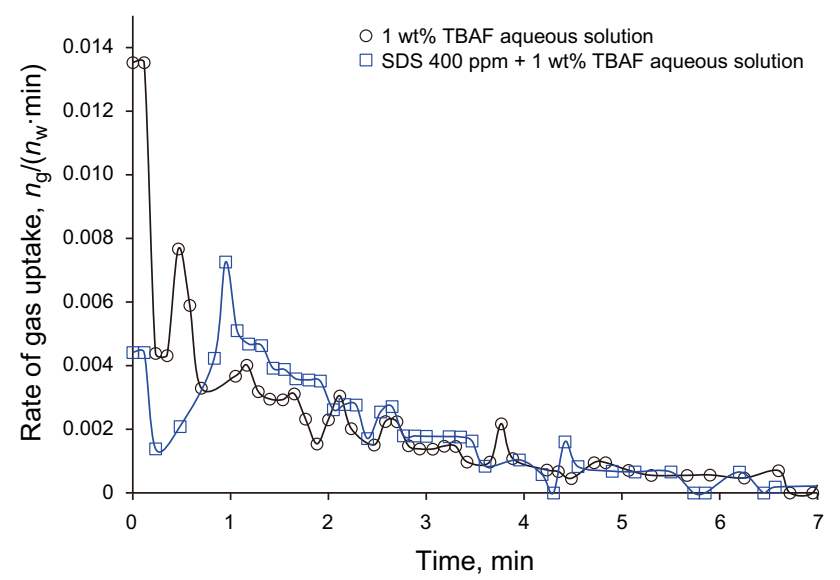

Fig. 11 The impact of SDS on the rate of $\mathrm{CO}_{2}$ uptake during hydrate formation in the presence of $1 \mathrm{wt} \% \mathrm{TBAF}$ aqueous solution, at an initial pressure of $3.8 \mathrm{MPa}$ and temperature of $5{ }^{\circ} \mathrm{C}$

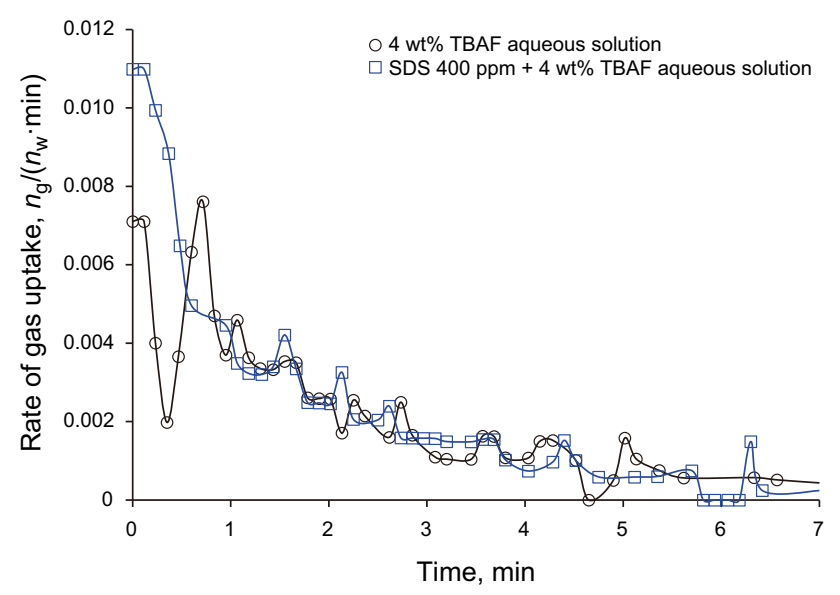

Fig. 12 The impact of SDS on the rate of $\mathrm{CO}_{2}$ uptake during hydrate formation in the presence of $4 \mathrm{wt} \% \mathrm{TBAF}$ aqueous solution, at an initial pressure of $3.8 \mathrm{MPa}$ and temperature of $5{ }^{\circ} \mathrm{C}$

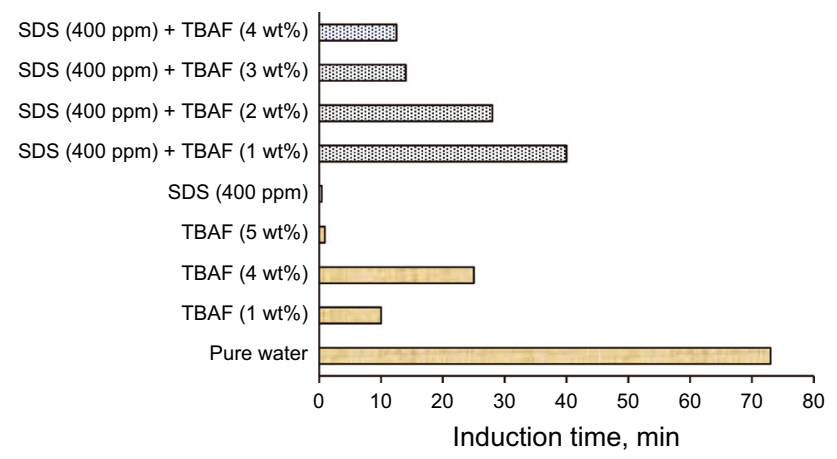

Fig. 13 The induction time of $\left(\mathrm{CO}_{2}+\mathrm{TBAF}\right)$ hydrate formation in the presence of SDS at an initial pressure of $3.8 \mathrm{MPa}$ and temperature of $5{ }^{\circ} \mathrm{C}$
Table 2 The induction time of $\mathrm{CO}_{2}$ hydrate formation or $\left(\mathrm{CO}_{2}\right.$ + TBAF) hydrate formation in the absence and the presence of SDS at an initial pressure of $3.8 \mathrm{MPa}$ and temperature of $5{ }^{\circ} \mathrm{C}$

\begin{tabular}{ll}
\hline System & $t_{\text {ind }}$ min \\
\hline $\mathrm{CO}_{2}+$ water & 73 \\
$\mathrm{CO}_{2}+$ TBAF $(1 \mathrm{wt} \%)+$ water & 10 \\
$\mathrm{CO}_{2}+$ TBAF $(4 \mathrm{wt} \%)+$ water & 25 \\
$\mathrm{CO}_{2}+\mathrm{TBAF}(5 \mathrm{wt} \%)+$ water & 0.9 \\
$\mathrm{CO}_{2}+\mathrm{SDS}(400 \mathrm{ppm})+$ water & 0.4 \\
$\mathrm{CO}_{2}+\mathrm{SDS}(400 \mathrm{ppm})+\mathrm{TBAF}(1 \mathrm{wt} \%)+$ water & 40 \\
$\mathrm{CO}_{2}+\mathrm{SDS}(400 \mathrm{ppm})+\mathrm{TBAF}(2 \mathrm{wt} \%)+$ water & 28 \\
$\mathrm{CO}_{2}+\mathrm{SDS}(400 \mathrm{ppm})+\mathrm{TBAF}(3 \mathrm{wt} \%)+$ water & 14 \\
$\mathrm{CO}_{2}+\mathrm{SDS}(400 \mathrm{ppm})+\mathrm{TBAF}(4 \mathrm{wt} \%)+$ water & 12.5 \\
\hline
\end{tabular}

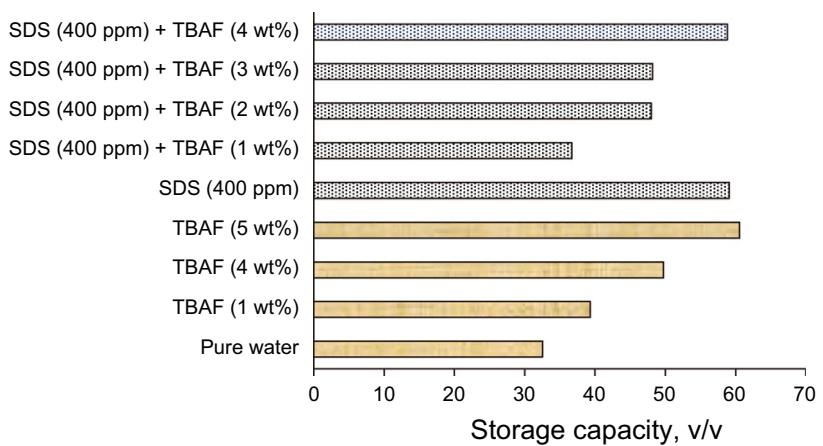

Fig. 14 The impact of SDS, TBAF, and the mixture of SDS + TBAF on storage capacity of $\mathrm{CO}_{2}$ in the process of hydrate formation at an initial pressure of $3.8 \mathrm{MPa}$ and temperature of $5{ }^{\circ} \mathrm{C}$

with $32.5 \mathrm{v} / \mathrm{v}$. This means that adding TBAF with $5 \mathrm{wt} \%$ increases the storage capacity of $\mathrm{CO}_{2}$ hydrate $86.1 \%$, compared to pure water. TBAF increased the storage capacity of $\mathrm{CO}_{2}$ hydrate formation by moderating the hydrate formation conditions.

The storage capacity of $\mathrm{CO}_{2}$ hydrate for aqueous solution of SDS with concentration of $400 \mathrm{ppm}$ was $59.1 \mathrm{v} / \mathrm{v}$. This means that adding $400 \mathrm{ppm}$ SDS increases the storage capacity of $\mathrm{CO}_{2}$ hydrate $81.6 \%$, compared to pure water. SDS improves the storage capacity of $\mathrm{CO}_{2}$ hydrate by decreasing the surface tension of water molecules.

\section{Conclusions}

In this study, the impacts of adding SDS, TBAF, and the mixture of SDS + TBAF on induction time, storage capacity, and the quantity and rate of gas uptake during $\mathrm{CO}_{2}$ hydrate formation were investigated. Our main conclusions can be summarized as follows: 
Table 3 Impacts of SDS, TBAF, and the mixture of SDS + TBAF on the storage capacity of $\mathrm{CO}_{2}$ and initial rate of $\mathrm{CO}_{2}$ uptake in the process of hydrate formation at an initial pressure of $3.8 \mathrm{MPa}$ and temperature of $5^{\circ} \mathrm{C}$

\begin{tabular}{|c|c|c|}
\hline Additive & $\begin{array}{l}\text { Storage } \\
\text { capacity, } \\
\text { V/V }\end{array}$ & $\begin{array}{l}\text { Initial rate of } \\
\mathrm{CO}_{2} \text { uptake } \times 100, \\
n_{\mathrm{g}} /\left(n_{\mathrm{w}} \cdot \min \right)\end{array}$ \\
\hline Pure water & 32.5 & 0.54 \\
\hline TBAF (1 wt $\%)$ & 39.3 & 1.35 \\
\hline TBAF (4 wt $\%$ ) & 49.7 & 0.71 \\
\hline TBAF (5 wt $\%$ ) & 60.6 & 0.82 \\
\hline SDS (400 ppm) & 59.1 & 1.67 \\
\hline SDS $(400 \mathrm{ppm})+$ TBAF $(1 \mathrm{wt} \%)$ & 36.7 & 0.44 \\
\hline SDS $(400 \mathrm{ppm})+\mathrm{TBAF}(2 \mathrm{wt} \%)$ & 48.0 & 0.52 \\
\hline SDS $(400 \mathrm{ppm})+$ TBAF $(3 \mathrm{wt} \%)$ & 48.2 & 1.10 \\
\hline SDS $(400 \mathrm{ppm})+$ TBAF $(4 \mathrm{wt} \%)$ & 58.8 & 1.16 \\
\hline
\end{tabular}

(1) The results show that adding SDS (400 ppm) and $\operatorname{TBAF}(5 \mathrm{wt} \%)$ increases the storage capacity of $\mathrm{CO}_{2}$ hydrate and decreases the induction time of hydrate formation considerably.

(2) Adding TBAF increases the quantity of $\mathrm{CO}_{2}$ uptake within $60 \mathrm{~min}$ of hydrate formation experiments, compared to pure water and the quantity of gas uptake during hydrate formation is proportional to the concentration of TBAF.

(3) Adding $400 \mathrm{ppm}$ SDS at low concentration of TBAF (1 wt \%), presents a negative effect on the quantity of gas uptake during hydrate formation process. By increasing the concentration of TBAF, the negative effect of SDS decreases.

(4) Finally, adding SDS and TBAF at tested conditions does not have a significant effect on increasing the rate of gas consumption.

Acknowledgements The financial support from the Iran National Science Foundation is greatly appreciated.

Open Access This article is distributed under the terms of the Creative Commons Attribution 4.0 International License (http://creative commons.org/licenses/by/4.0/), which permits unrestricted use, distribution, and reproduction in any medium, provided you give appropriate credit to the original author(s) and the source, provide a link to the Creative Commons license, and indicate if changes were made.

\section{References}

Adisasmito S, Frank RJ III, Sloan ED Jr. Hydrates of carbon dioxide and methane mixtures. J Chem Eng Data. 1991;36(1):68-71. https://doi.org/10.1021/je00001a020.

Arjang S, Manteghian M, Mohammadi A. Effect of synthesized silver nanoparticles in promoting methane hydrate formation at
4.7 MPa and 5.7 MPa. Chem Eng Res Des. 2013;91(6):1050-4. https://doi.org/10.1016/j.cherd.2012.12.001.

Babaee S, Hashemi H, Mohammadi AH, Naidoo P, Ramjugernath D. Kinetic and thermodynamic behaviour of CF 4 clathrate hydrates. J Chem Thermodyn. 2015;81:52-9. https://doi.org/10. 1016/j.jct.2014.09.008.

Belandria V, Eslamimanesh A, Mohammadi AH, Richon D. Gas hydrate formation in carbon dioxide + nitrogen + water system: compositional analysis of equilibrium phases. Ind Eng Chem Res. 2011;50(8):4722-30. https://doi.org/10.1021/ ie101635k.10.1021/ie101635k.

Belandria V, Mohammadi AH, Eslamimanesh A, Richon D, SanchezMora MF, Galicia-Luna LA. Phase equilibrium measurements for semi-clathrate hydrates of the $\left(\mathrm{CO}_{2}+\mathrm{N}_{2}+\right.$ tetra-n-butylammonium bromide) aqueous solution systems: part 2. Fluid Phase Equilib. 2012;322:105-12. https://doi.org/10.1016/j.fluid. 2012.02.020.

Bhattacharjee G, Kumar A, Sakpal T, Kumar R. Carbon dioxide sequestration: influence of porous media on hydrate formation kinetics. ACS Sustain Chem Eng. 2015;3(6):1205-14. https:// doi.org/10.1021/acssuschemeng.5b00171.

Bi Y, Guo T, Zhang L, Zhang H, Chen L. Experimental study on cool release process of gas-hydrate with additives. Energy Build. 2009;41(1):120-4. https://doi.org/10.1016/j.enbuild.2008.08. 004.

Bonamico M, Jeffrey GA, McMullan RK. Polyhedral clathrate hydrates. III. Structure of the tetra n-butyl ammonium benzoate hydrate. J Chem Phys. 1962;37(10):2219-31. https://doi.org/10. 1063/1.1732990.

Chatti I, Delahaye A, Fournaison L, Petitet JP. Benefits and drawbacks of clathrate hydrates: a review of their areas of interest. Energy Convers Manag. 2005;46(9):1333-43. https:// doi.org/10.1016/j.enconman.2004.06.032.

Dashti $\mathrm{H}$, Yew LZ, Lou X. Recent advances in gas hydrate-based $\mathrm{CO}_{2}$ capture. J Nat Gas Sci Eng. 2015;23:195-207. https://doi.org/10. 1016/j.jngse.2015.01.033.

Delahaye A, Fournaison L, Marinhas S, Chatti I, Petitet JP, Dalmazzone D, et al. Effect of THF on equilibrium pressure and dissociation enthalpy of $\mathrm{CO}_{2}$ hydrates applied to secondary refrigeration. Ind Eng Chem Res. 2006;45(1):391-7. https://doi. org/10.1021/ie050356p.

Eslamimanesh A, Mohammadi AH, Richon D, Naidoo P, Ramjugernath D. Application of gas hydrate formation in separation processes: a review of experimental studies. J Chem Thermodyn. 2012;46:62-71. https://doi.org/10.1016/j.jct.2011.10.006.

Fan SS, Du J, Wang YH, Lang XM. Growth kinetics of Tetra-N-Butyl ammonium bromide semiclathrate hydrate through concentration determination and microscopic observation. In: Fan W (ed) Advanced materials research. Trans Tech Publ: 2011. p. 3121-27. https://doi.org/10.4028/www.scientific.net/AMR. 383-390.3121.

Farhang F, Nguyen AV, Sewell KB. Fundamental investigation of the effects of hydrophobic fumed silica on the formation of carbon dioxide gas hydrates. Energy Fuels. 2014;28(11):7025-37. https://doi.org/10.1021/ef5009133.

Fazlali A, Kazemi SA, Keshavarz-Moraveji M, Mohammadi AH. Impact of different surfactants and their mixtures on methane hydrate formation. Energy Technol. 2013;1(8):471-7. https:// doi.org/10.1002/ente.201300041.

Fowler DL, Loebenstein WV, Pall DB, Kraus CA. Some unusual hydrates of quaternary ammonium salts. J Am Chem Soc. 1940;62(5):1140-2. https://doi.org/10.1021/ja01862a039.

Ganji H, Manteghian M, Rahimi Mofrad H. Effect of mixed compounds on methane hydrate formation and dissociation rates and storage capacity. Fuel Process Technol. 2007a;88(9):891-5. https://doi.org/10.1016/j.fuproc.2007.04.010. 
Ganji H, Manteghian M, Sadaghiani Zadeh K, Omidkhah MR, Rahimi Mofrad H. Effect of different surfactants on methane hydrate formation rate, stability and storage capacity. Fuel. 2007b;86(3):434-41. https://doi.org/10.1016/j.fuel.2006.07.032.

Herzog $\mathrm{H}$, Drake E, Adams E. $\mathrm{CO}_{2}$ capture, reuse, and storage technologies for mitigating global climate change. A White Paper. Energy Laboratory Massachusetts Institute of Technology; 1997.

Hughes TJ. Plug formation and dissociation of mixed gas hydrates and methane semi-clathrate hydrate stability. doctor of philosophy thesis. university of Canterbury. Christchurch. 2008.

Jager M, De Deugd R, Peters C, de Swaan Arons J, Sloan E. Experimental determination and modeling of structure II hydrates in mixtures of methane + water +1 , 4-dioxane. Fluid Phase Equilib. 1999;165(2):209-23. https://doi.org/10.1016/ S0378-3812(99)00278-2.

Javanmardi J, Moshfeghian M. Energy consumption and economic evaluation of water desalination by hydrate phenomenon. Appl Therm Eng. 2003;23(7):845-57. https://doi.org/10.1016/S13594311(03)00023-1.

Ji C, Ahmadi G, Smith DH. Natural gas production from hydrate decomposition by depressurization. Chem Eng Sci. 2001;56(20):5801-14. https://doi.org/10.1016/S00092509(01)00265-2.

Kang SP, Lee JW. Kinetic behaviors of $\mathrm{CO}_{2}$ hydrates in porous media and effect of kinetic promoter on the formation kinetics. Chem Eng Sci. 2010;65(5):1840-5. https://doi.org/10.1016/j.ces.2009. 11.027.

Kohl AL, Nielsen RB. Gas purification. 5th ed. Houston: Gulf Professional Publishing; 1997.

Komarov VY, Rodionova TV, Terekhova IS, Kuratieva NV. The cubic superstructure-I of tetrabutylammonium fluoride $\left(\mathrm{C}_{4} \mathrm{H}_{9}\right) 4$ NF.29.7 $\mathrm{H}_{2} \mathrm{O}$ Clathrate hydrate. J Incl Phenom Macrocycl Chem. 2007;59(1-2):11-5. https://doi.org/10.1007/s10847-006-9151-9.

Kumar A, Sakpal T, Linga P, Kumar R. Influence of contact medium and surfactants on carbon dioxide clathrate hydrate kinetics. Fuel. 2013;105:664-71. https://doi.org/10.1016/j.fuel.2012.10. 031.

Kuramochi T, Ramírez A, Turkenburg W, Faaij A. Comparative assessment of $\mathrm{CO}_{2}$ capture technologies for carbon-intensive industrial processes. Prog Energy Combust Sci. 2012;38(1):87-112. https://doi.org/10.1016/j.pecs.2011.05.001.

Li G, Hwang Y, Radermacher R. Review of cold storage materials for air conditioning application. Int J Refrig. 2012;35(8):2053-77. https://doi.org/10.1016/j.ijrefrig.2012.06.003.

Li S, Fan S, Wang J, Lang X, Wang Y. Semiclathrate hydrate phase equilibria for $\mathrm{CO}_{2}$ in the presence of tetra-n-butyl ammonium halide (bromide, chloride, or fluoride). J Chem Eng Data. 2010;55(9):3212-5. https://doi.org/10.1021/je100059h.

Lirio CFdS, Pessoa FLP, Uller AMC. Storage capacity of carbon dioxide hydrates in the presence of sodium dodecyl sulfate (SDS) and tetrahydrofuran (THF). Chem Eng Sci. 2013;96(0):118-23. https://doi.org/10.1016/j.ces.2012.10.022.

Lu T, Zhang Y, Li X, Chen Z, Yan K. Equilibrium conditions of hydrate formation in the systems of $\mathrm{CO}_{2}-\mathrm{N}_{2}-\mathrm{TBAB}$ and $\mathrm{CO}_{2}-\mathrm{N}_{2}-$ THF. Chinese J Process Eng. 2009;3:023. https://doi.org/10. 1016/j.fluid.2015.09.021.

Makino T, Yamamoto T, Nagata K, Sakamoto H, Hashimoto S, Sugahara T, Ohgaki K. Thermodynamic stabilities of tetra-nbutyl ammonium chloride $+\mathrm{H}_{2}, \mathrm{~N}_{2}, \mathrm{CH}_{4}, \mathrm{CO}_{2}$, or $\mathrm{C} 2 \mathrm{H} 6$ semiclathrate hydrate systems. J Chem Eng Data. 2009;55(2):839-41. https://doi.org/10.1021/je9004883.

Manteghian M, Mousavi Safavi SM, Mohammadi A. The equilibrium conditions, hydrate formation and dissociation rate and storage capacity of ethylene hydrate in presence of 1,4-dioxane. Chem
Eng J. 2013;217:379-84. https://doi.org/10.1016/j.cej.2012.12. 014.

McMullan RK, Bonamico M, Jeffrey GA. Polyhedral clathrate hydrates. V. structure of the tetra-n-butyl ammonium fluoride hydrate. J Chem Phys. 1963;39(12):3295-310. https://doi.org/10. 1063/1.1734193.

Mohammadi A, Manteghian M, Haghtalab A, Mohammadi AH, Rahmati-Abkenar M. Kinetic study of carbon dioxide hydrate formation in presence of silver nanoparticles and SDS. Chem Eng J. 2014a;237:387-95. https://doi.org/10.1016/j.cej.2013.09. 026.

Mohammadi A, Manteghian M, Mohammadi AH. Dissociation data of semiclathrate hydrates for the systems of tetra-n-butylammonium fluoride $(\mathrm{TBAF})+$ methane + water, $\mathrm{TBAF}+$ carbon dioxide + water, and TBAF + nitrogen + water. J Chem Eng Data. 2013;58(12):3545-50. https://doi.org/10.1021/je4008519.

Mohammadi A, Manteghian M, Mohammadi AH. Phase equilibria of semiclathrate hydrates for methane + tetra n-butylammonium chloride (TBAC), carbon dioxide + TBAC, and nitrogen + TBAC aqueous solution systems. Fluid Phase Equilib. 2014b;381:102-7. https://doi.org/10.1016/j.fluid.2014.08.012.

Mohammadi AH, Eslamimanesh A, Belandria V, Richon D, Naidoo $\mathrm{P}$, Ramjugernath D. Phase equilibrium measurements for semiclathrate hydrates of the $\left(\mathrm{CO}_{2}+\mathrm{N}_{2}+\right.$ tetra-n-butylammonium bromide) aqueous solution system. J Chem Thermodyn. 2012;46:57-61. https://doi.org/10.1016/j.jct.2011.10.004.

Mohammadi AH, Richon D. Phase equilibria of semi-clathrate hydrates of tetra-n-butylammonium bromide + hydrogen sulfide and tetra-n-butylammonium bromide + methane. J Chem Eng Data. 2009;55(2):982-4. https://doi.org/10.1021/je9004257.

Ohgaki K, Takano K, Sangawa H, Matsubara T, Nakano S. Methane exploitation by carbon dioxide from gas hydrates. Phase equilibria for $\mathrm{CO}_{2}-\mathrm{CH}_{4}$ mixed hydrate system. J Chem Eng Jpn. 1996;29(3):478-83. https://doi.org/10.1252/jcej.29.478.

Papadimitriou NI, Tsimpanogiannis IN, Stubos AK, Martín A, Rovetto LJ, Florusse LJ, Peters CJ. Experimental and computational investigation of the sII binary He - THF hydrate. J Phys Chem B. 2011;115(6):1411-5. https://doi.org/10.1021/ jp $105451 \mathrm{~m}$.

Peng P, Zhuang Y. The evaluation and comparison of carbon dioxide capture technologies applied to FCC flue gas. Advanced Materials Research. Trans Tech Publ; 2012. p. 1479-82. 10.4028/www.scientific.net/AMR.347-353.1479.

Ricaurte M, Dicharry C, Renaud X, Torré JP. Combination of surfactants and organic compounds for boosting $\mathrm{CO}_{2}$ separation from natural gas by clathrate hydrate formation. Fuel. 2014;122:206-17. https://doi.org/10.1016/j.fuel.2014.01.025.

Riemer P. Greenhouse gas mitigation technologies, an overview of the $\mathrm{CO}_{2}$ capture, storage and future activities of the IEA greenhouse gas R\&D programme. Energy Convers Manag. 1996;37(6):665-70. https://doi.org/10.1016/01968904(95)00237-5.

Rogers R, Zhang G, Dearman J, Woods C. Investigations into surfactant/gas hydrate relationship. J Pet Sci Eng. 2007;56(1-3):82-8. https://doi.org/10.1016/j.petrol.2005.07.006.

Roosta H, Khosharay S, Varaminian F. Experimental and modeling investigation on mixed carbon dioxide-tetrahydrofuran hydrate formation kinetics in isothermal and isochoric systems. J Mol Liq. 2015;211:411-6. https://doi.org/10.1016/j.molliq.2015.07. 065.

Sabil KM, Duarte ARC, Zevenbergen J, Ahmad MM, Yusup S, Omar AA, et al. Kinetic of formation for single carbon dioxide and mixed carbon dioxide and tetrahydrofuran hydrates in water and sodium chloride aqueous solution. Int J Greenh Gas Control. 2010;4(5):798-805. https://doi.org/10.1016/j.ijggc.2010.05.010. 
Sloan D. Natural gas hydrates in flow assurance. Boston: Gulf Professional Publishing; 2011. p. 1-11.

Sloan JED, Koh KA. Clathrate hydrates of natural gases. 3rd ed. Taylor \& Francis Group: CRC Press; 2008.

Smith JM, Van Ness H, Abbott M. Introduction to chemical engineering thermodynamics. New York: McGraw-Hill; 2001.

Strobel TA, Taylor CJ, Hester KC, Dec SF, Koh CA, Miller KT, Sloan E. Molecular hydrogen storage in binary THF- $\mathrm{H}_{2}$ clathrate hydrates. J Phys Chem B. 2006;110(34):17121-5. https://doi.org/ 10.1021/jp062139n.

Sun CY, Chen GJ, Zhang LW. Hydrate phase equilibrium and structure for (methane + ethane + tetrahydrofuran + water) system. J Chem Thermodyn. 2010;42(9):1173-9. https://doi. org/10.1016/j.jct.2010.04.021.

Tanii T. Energy storage: low temperature heat storage (use of clathrate). J Jpn Soc Mech Eng. 1994;97:925-7.

Torré JP, Dicharry C, Ricaurte M, Daniel-David D, Broseta D. $\mathrm{CO}_{2}$ capture by hydrate formation in quiescent conditions: in search of efficient kinetic additives. Energy Procedia. 2011;4:621-8. https://doi.org/10.1016/j.egypro.2011.01.097.

UNFCCC. Adoption of the Paris agreement-Proposal by the President-, Paris, pp. 1-12; 2015.

Vlahakis JG, Chen HS, Suwandi MS, Barduhn AJ. The growth rate of ice crystals: the properties of carbon dioxide hydrate, a review of properties of 51 gas hydrates, Syracuse U. Research and Development Report 830, prepared for US Department of the Interior; 1972.

$\mathrm{Xu} \mathrm{Q}$, Ge J. Reduction of $\mathrm{CO}_{2}$ emission using bioreactor technology for waste management in China. Energy Procedia. 2011;5:1026-31. https://doi.org/10.1016/j.egypro.2011.03.181.
Ye N, Zhang $\mathrm{P}$, Liu QS. Kinetics of hydrate formation in the $\mathrm{CO}_{2}+\mathrm{TBAB}+\mathrm{H}_{2} \mathrm{O}$ system at low mass fractions. Ind Eng Chem Res. 2014;53(24):10249-55. https://doi.org/10.1021/ ie5012504.

Zhang B, Wu Q. Thermodynamic promotion of tetrahydrofuran on methane separation from low-concentration coal mine methane based on hydrate. Energy Fuels. 2010;24(4):2530-5. https://doi. org/10.1021/ef901446n.

Zhang B, Wu Q, Zhu Y. Effect of THF on the thermodynamics of low-concentration gas hydrate formation. J China Univ Min Technol. 2009;38(2):203-8.

Zhang CS, Fan SS, Liang DQ, Guo KH. Effect of additives on formation of natural gas hydrate. Fuel. 2004;83(16):2115-21. https://doi.org/10.1016/j.fuel.2004.06.002.

Zhang J, Lo C, Somasundaran P, Lu S, Couzis A, Lee J. Adsorption of sodium dodecyl sulfate at THF hydrate/liquid interface. J Phys Chem C. 2008;112(32):12381-5. https://doi.org/10.1021/ jp801963c.

Zhang JS, Lee S, Lee JW. Kinetics of methane hydrate formation from SDS solution. Ind Eng Chem Res. 2007;46(19):6353-9. https://doi.org/10.1021/ie070627r.

Zhang LW, Huang Q, Sun CY, Ma QL, Chen GJ. Hydrate formation conditions of methane + ethylene + tetrahydrofuran + water systems. J Chem Eng Data. 2006;51(2):419-22. https://doi.org/ 10.1021/je050342q.

Zhao J, Zhao Y, Shi D. Experiment on methane concentration from oxygen-containing coal bed gas by THF solution hydrate formation. J China Coal Soc. 2008;12:1419-24. 